DOI 10.31558/2307-2318.2019.4.18

УДК 005.5:504.064

Семеніхіна В.В., старший викладач, Кременчуцький національний університет імені Михайла Остроградського

\title{
СОЦІО-ЕКОЛОГІЧНИЙ ВЕКТОР РОЗВИТКУ ДІЯЛЬНОСТІ СУЧАСНОГО УСПІШНОГО ПІДПРИЕМСТВА
}

Обгрунтовано необхідність трансформації стратегії розвитку сучасного підприємства у бік іiі орієнтації на дві основні складові - безперервний розвиток і створення сприятливих умов діяльності людини та екологічна безпека технологічного циклу функціонування підприємства. Доведено, що лише дотримання вимог соціальної відповідальності дозволить підприємству набути ознак економічної успішності та сформувати ефективний бренд роботодавця. Проаналізовано складові ціннісної орієнтації стратегії розвитку п'яти найбільш ефективних роботодавців світу за версією The world's best employers 2019. Сформульовано основні принципи діяльності провідних роботодавців світу у напрямі соціо-екологічного забезпечення: збалансоване використання всіх факторів виробництва; ощадливе відношення до навколишнього середовища; професійний розвиток персоналу протягом життя та орієнтація на таланти; соціальний діалог і суспільна відповідальність.

Ключові слова: підприємство, вектор розвитку діяльності, соціальна відповідальність, екологічна безпека, ефективний бренд роботодавця

Рис. -5 , Табл. -1 , Літ. -23.

\section{Семенихина В.В.}

\section{СОЦИО-ЭКОЛОГИЧЕСКИЙ ВЕКТОР РАЗВИТИЯ ДЕЯТЕЛЬНОСТИ СОВРЕМЕННОГО УСПЕШНОГО ПРЕДПРИЯТИЯ}

Обоснована необходимость трансформации стратегии развития современного предприятия в сторону ее ориентации на две основные составляющие - непрерывное развитие и создание благоприятных условий деятельности человека и экологическая безопасность технологического цикла функционирования предприятия. Доказано, что только соблюдение требований социальной ответственности позволит предприятию достигнуть признаков экономической успешности и сформировать эффективный бренд работодателя. Проанализированы составляющие ценностной ориентации стратегии развития пяти наиболее эффективных работодателей мира по версии The world's best employers 2019. Сформулированы основные принципы деятельности ведущих работодателей мира в направлении социо-экологического обеспечения: сбалансированное использование всех факторов производства; экономное отношение к окружающей среде; профессиональное развитие персонала в течение жизни и ориентация на таланты; социальный диалог и общественная ответственность.

Ключевые слова: предприятие, вектор развития деятельности, социальная ответственность, экологическая безопасность, эффективный бренд работодателя

\section{Semenikhina V. SOCIO-ECOLOGICAL VECTOR OF DEVELOPMENT OF ACTIVITY OF A MODERN SUCCESSFUL ENTERPRISE}

The necessity of transforming the development strategy of a modern enterprise in the direction of its focus on two main components - the continuous development and creation of favorable conditions for human activities and the environmental safety of the technological cycle of the enterprise's functioning, is substantiated. It is proved that only compliance with the 
requirements of social responsibility will allow the company to achieve signs of economic success and to form an effective employer brand. The components of the value orientation of the development strategy of the five most effective employers in the world according to The world's best employers 2019 are analyzed. The basic principles of the activities of the world's leading employers in the direction of socio-environmental support are formulated: balanced use of all factors of production; economical attitude to the environment; professional development of staff throughout life and orientation to talents; social dialogue and social responsibility.

Key words: enterprise, activity development vector, social responsibility, environmental safety, effective employer brand

Постановка проблеми та її зв'язок з важливими науковими чи практичними завданнями. Техніко-технологічна еволюція цивілізації кардинальним чином змінила життя людини: підвищила його рівень, якість і комфортність, урізноманітнила та наповнила новими атрибутами, змістами, цілями та інструментами їх досягнення. Водночас поступово, протягом кількох останніх століть, відбувалася трансформація ціннісних орієнтацій людини з суто соціальних та суспільних, таких як можливість спілкування, сумісного відпочинку, культурного розвитку, любування природою й спостереження за тваринами, на матеріальні, що сьогодні відіграють головну роль у житті людини та суспільства. Такий перехід супроводжувався надмірним накопиченням матеріальних благ, процеси виготовлення, експлуатації та утилізації яких суттєвим чином порушували природний баланс, погіршували екологічну обстановку та катастрофічно зменшували запаси природних ресурсів планети, що негативним чином позначилося на якості харчування, питної води та повітря, а у результаті - на здоров'ї та тривалості життя людини у сучасному світі. Запровадження дієвих заходів щодо припинення та подальшого запобігання означених тенденцій стало одним 3 актуальних векторів перспективного розвитку ефективного бізнес-середовища розвинених країн світу, які питання екологічної безпеки захисту довкілля та соціального забезпечення базових потреб людини визнають як першочергові. Ретельне дослідження означеного досвіду має стати основою для розробки стратегій соціо-екологічного розвитку вітчизняних підприємств та поштовхом для початку практичної реалізації означених стратегій.

Аналіз останніх досліджень і публікацій 3 проблеми, що розглядається. Соціальні та екологічні виклики обрані не лише світовими лідерами інноваційного руху в якості стратегічної мети розвитку, їх також покладено в основу досліджень провідних науковців світу. Висвітлення екологічних аспектів управління сучасним підприємством спрямовано здебільшого у бік теоретико-методологічного обгрунтування їх економічної доцільності. Так, А. Садеков сформував та визначив методико-методологічний апарат еколого-економічного управління підприємством [1]. В. Дерій надав характеристику сутності й стану та визначив напрями розвитку процедур обліку, аудиту і аналізу екологічної діяльності підприємств [2]. Д. Грицишен обгрунтував методологію екологоекономічного аналізу господарської діяльності промислових підприємств [3]. О. Латишева виокремила та надала сутнісної характеристики етапам управління екологічною складовою потенціалу розвитку промислових підприємств [4]. Л. Скляр визначив зміст, принципи та складові екологічного управління підприємством [5]. О. Фещенко й Н. Камнева визначили сутність та компоненти еколого-економічної безпеки підприємства [6]. О. Прокопенко та В. Школа розробили методику оцінки відповідності екологічних технологічних підходів підприємства інтересам стейкхолдерів 
ринку [7]. Г. Швиданенко, О. Криворучкіна та Д. Матукова розкрили особливості адаптації провідного світового досвіду вирішення проблем у сфері еколого-економічних аспектів управління підприємством [8].

Розкриттю соціальних аспектів у структурі технології управління підприємством також приділено достатньо уваги науковців. Так, Е. Лібанова обгрунтувала внутрішні виклики українського суспільства, одним з яких обрала соціальну нерівність [9]. А. Колот окреслив еволюцію та напрями розвитку теоретичних підходів до формування корпоративної соціальної відповідальності [10]. О.Грішнова та І. Магдич довели необхідність активізації соціальних інвестицій українських підприємств [11]. О. Новікова, М. Дейч та В. Панькова надали оцінку досягнутого стану та перспективам розвитку соціальної відповідальності в Україні [12]. І. Комарницький й 3. Галушка визначили соціальну відповідальність важливим інструмент управління підприємством [13].

Водночас, не зважаючи на досить потужний теоретичний вклад науковців у справу доведення доцільності переходу суб'єктів господарювання на соціо-екологічний аспект управління, на практиці означена проблематика залишається нерозв'язаною. Саме тому існує необхідність у більш глибокому дослідження саме практичної складової означеної тематики, що пропонується здійснити на основі вивчення провідного світового досвіду.

Отже, метою даного дослідження було обрано обгрунтування принципів соціоекологічного вектору розвитку діяльності сучасного успішного підприємства.

Виклад основного матеріалу. В економічній теорії існує достатньо кількісних показників виміру результативності та ефективності діяльності підприємства, кожен 3 яких характеризує лише окрему складову його діяльності, той чи інший аспект функціонування на конкретний період часу. Отримати ж комплексний результат оцінки щодо реального місця підприємства у регіональній та національній економіці та прогноз щодо перспектив його розвитку у коротко-, середньо та довготривалому періоді часу виключно за кількісними показниками досить складно. До того ж орієнтація виключно на економічні показники також не дозволить отримати повної картини щодо рівня розвитку та потенціалу підприємства, ступеня його соціальної відповідальності. Для цього мають бути використаними інші підходи до оцінки, що крім кількісних показників базуються також і на якісних індикаторах, характеристиках соціо-екологічного вектору розвитку підприємства. Одним з таких підходів є оцінка сформованого підприємством на ринку бренду роботодавця, що у загальному вигляді характеризується як «позитивний імідж та беззаперечна довіра, сприйняття підприємства як надійного партнера, відповідального роботодавця, привабливого для своєї цільової аудиторії сьогодні і у майбутньому» [14]. При цьому у результаті зростання ступеня привабливості бренду роботодавця буде відбуватися відповідні позитивні зрушення у значеннях всіх кількісних показників, що визначають ефективність управління персоналом та підприємством в цілому [15]. Отже саме виконання суб'єктами господарювання всього комплексу вимог соціальної відповідальності дозволяє досягти статусу привабливого бренда роботодавця, що виступає дієвим важелем підвищення його конкурентоспроможності на ринку та має забезпечити зростання рівня економічної результативності діяльності на перспективу.

Компанії, що досягли значних здобутків у процесі формування власного бренда роботодавця щорічно потрапляють до рейтингу The world's best employers, який на підгрунті технологій глобальних й регіональних опитувань респондентів по всьому світу й опрацюванні великої кількості рекомендацій з працевлаштування, американський журнал Forbes разом із німецьким онлайн-порталом статистики Statista складають третій 
рік поспіль Топ 500 найкращих роботодавців світу у переліку Global 2000 [16]. За даними 2019 р. жодна українська компанія не увійшла до рейтингу The world's best employers 2019 list, що свідчить про недостатність приділення діловим середовищем України уваги процесам формування успішного бренда роботодавця та необхідність адаптації провідного світового досвіду, нагромадженого у цій сфері. 3 цією метою в роботі буде проаналізовано діяльність компаній, які у 2019 р. посіли перші п'ять місць у рейтингу роботодавців світу, табл. 1.

Таблиця 1

Перша п'ятірка компаній рейтингу The world's best employers 2019

\begin{tabular}{|c|c|c|c|c|c|c|}
\hline $\begin{array}{l}\text { Місце } \\
\text { у рей- } \\
\text { тингу }\end{array}$ & Компанія & Країна & Галузь & \begin{tabular}{|c} 
Місце у \\
рейтингу \\
Top 100 \\
Digital \\
Companies \\
2019
\end{tabular} & \begin{tabular}{|c} 
Місце \\
у рейтингу \\
Toп 50 World's \\
Most Innovative \\
Companies \\
2019
\end{tabular} & $\begin{array}{c}\text { Місце } \\
\text { у рейтингу } \\
\text { Global } 2000 \\
2019\end{array}$ \\
\hline 1 & Alphabet & США & Комп’ютерні послуги & 4 & 1 & 17 \\
\hline 2 & Microsoft & США & $\begin{array}{c}\text { Програмне забезпечення } \\
\text { та програмування }\end{array}$ & 2 & 4 & 16 \\
\hline 3 & Red Hat & США & $\begin{array}{c}\text { Програмне забезпечення } \\
\text { та програмування }\end{array}$ & 48 & $\begin{array}{c}24 \text { за даними } \\
\text { рейтингу } 2018 \text { р. }\end{array}$ & 1464 \\
\hline 4 & Apple & США & Комп’ютерна техніка & 1 & 3 & 6 \\
\hline 5 & SAP & Німеччина & $\begin{array}{c}\text { Програмне забезпечення } \\
\text { та програмування }\end{array}$ & 22 & 28 & 176 \\
\hline
\end{tabular}

Джерело: побудовано автором за даними [16; 17]

Bсі п’ять компаній, що потрапили в 2019 р. до Топ 5 The world's best employers 2019, відносяться до різних сфер однієї галузі - цифрової індустрії, що красномовно свідчить про вектор розвитку сучасного світового ділового середовища, що вже остаточно намітився й сформувався. До того ж всі компанії потрапили у 2019 р. до Топ 50 Digital Companies 2019, що свідчить про їх потужний технологічний рівень та високу конкурентоспроможність на сучасному світовому ринку цифрових технологій. У комплексі це дозволило трьом (Alphabet, Apple та Microsoft) 3 п'яти компаній увійти до Toп 4 World's Most Innovative Companies, що характеризує їх як визнаних найбільших інноваторів світу. Саме тому детальне дослідження векторів соціально-екологічного розвитку означених компаній має надати можливість встановити узагальнені принципи ефективного соціально відповідального напряму функціонування сучасного підприємства, які у подальшому мають бути адаптованими та найшвидше імплементованими в діяльність українських суб'єктів господарювання.

За вихідну інформаційну базу дослідження було прийнято дані, наведені на офіційних сайтах кожної з п'яти компаній-лідерів рейтингу The world's best employers 2019. Узагальнення та опрацювання означеної інформації дозволило зробити такі висновки у контексті нашого дослідження.

Американську компанію Alphabet Inc. було створено у жовтні 2015 р. як материнську холдингову компанію, що об'єднала кілька дочірніх компаній, таких як Google, Calico, CapitalG, Chronicle, DeepMind, Google Fiber, GV, Jigsaw та інші [18]. Miciєю Alphabet Inc. стало розширення можливостей людини за рахунок більш розумного використання даних. До того ж метою діяльності нової компанії було обрано розв'язання за допомогою новітніх технологій надскладних задач, що постійно 3'являються в житті сучасної людини. 3 цією метою Alphabet Inc. цілеспрямовано веде 
відбір спеціалізованих компаній, які купує та інвестує кошти у їх технологічний розвиток. Детальний аналіз останнього квартального звіту, оприлюдненого на сайті компанії дозволив сформулювати основні вектори діяльності холдингу в руслі соціоекологічного напряму (рис. 1).

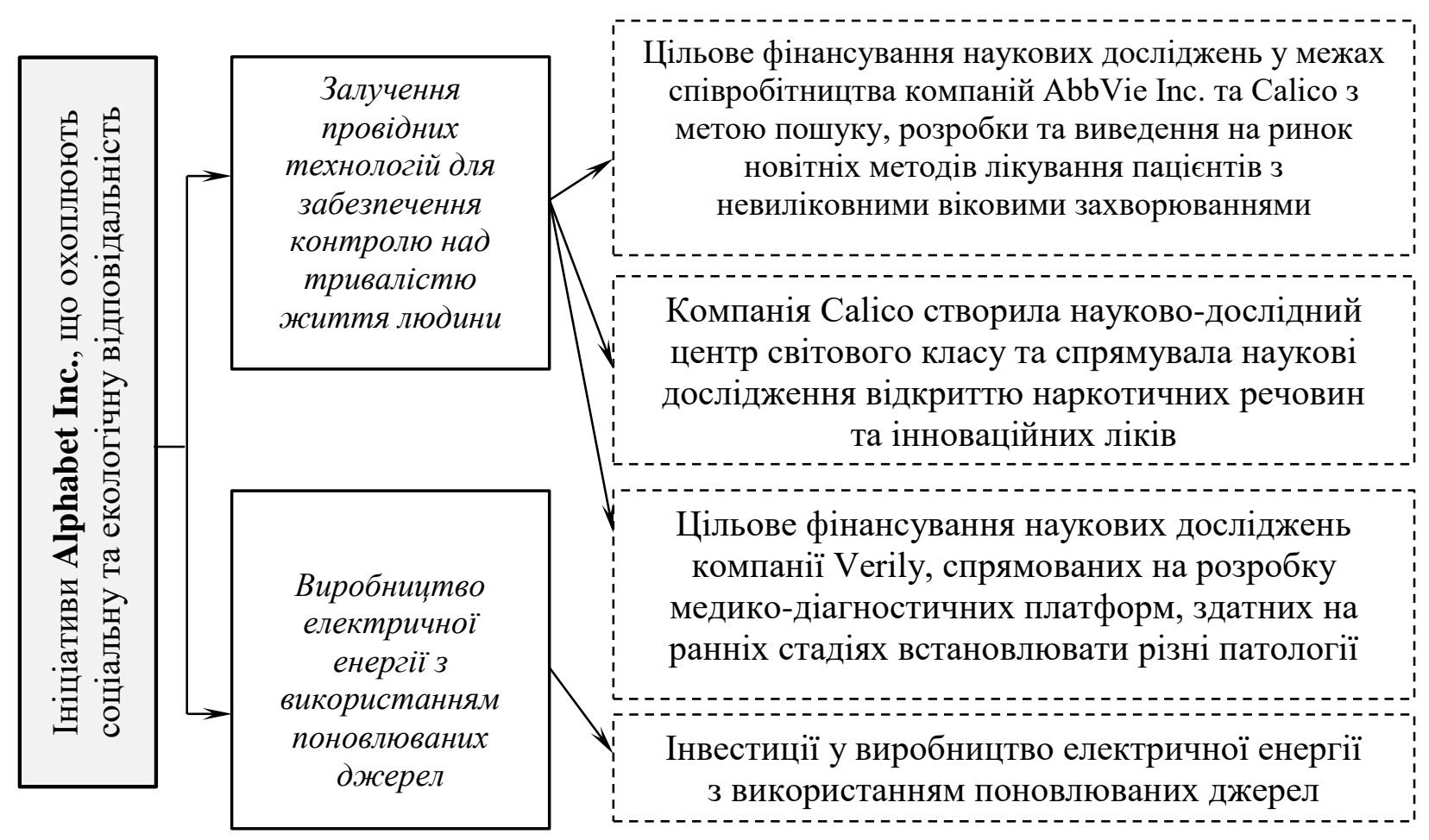

\section{Рисунок 1 - Соціо-екологічні оріснтири діяльності компанії Alphabet Inc. Джерело: побудовано автором за даними [19]}

Отже можна стверджувати, що основний вектор соціальної відповідальності компанії Alphabet Inc. спрямований на забезпечення здорового, повноцінного та довгого життя людині й виробництво електричної енергії 3 використанням поновлюваних джерел.

Транснаціональна корпорація Microsoft Corporation була заснованою у жовтні 1976 р., штаб-кватира якої знаходиться у американському м. Реймонд. Місія компанії надання можливостей кожній людині та кожній організації на планеті для досягнення більшого. Цільовим орієнтиром бізнес-культури компанії $\epsilon$ неперервний процес залучення молодих професіоналів до розробки програмних продуктів, з метою реалізації якого Microsoft щорічно здійснює значні обсяги інвестицій у пошук, залучення та розвиток талантів. Процес пошуку й утримання талантів характеризується широкомасштабністю та включає активну роботу з випускниками шкіл, та, у першу чергу, з особами жіночої статі та представниками національних меншин; залучення колишніх та теперішніх програмістів до прийняття управлінських рішень; надання вільного графіку роботи та широкого спектру соціальних послуг працівникам тощо [20]. Компанія чітко позиціонує високу пряму залежність між фінансово-економічною успішністю свого бізнесу та здатністю залучати та утримувати талановитих працівників. Саме тому пріоритетом для компанії є фізичне, емоційне та фінансове благополуччя працівників та членів їх родин. 
Компанія генерує та реалізовує широкий спектр ініціатив за напрямом соціоекологічного вектору розвитку (рис. 2).

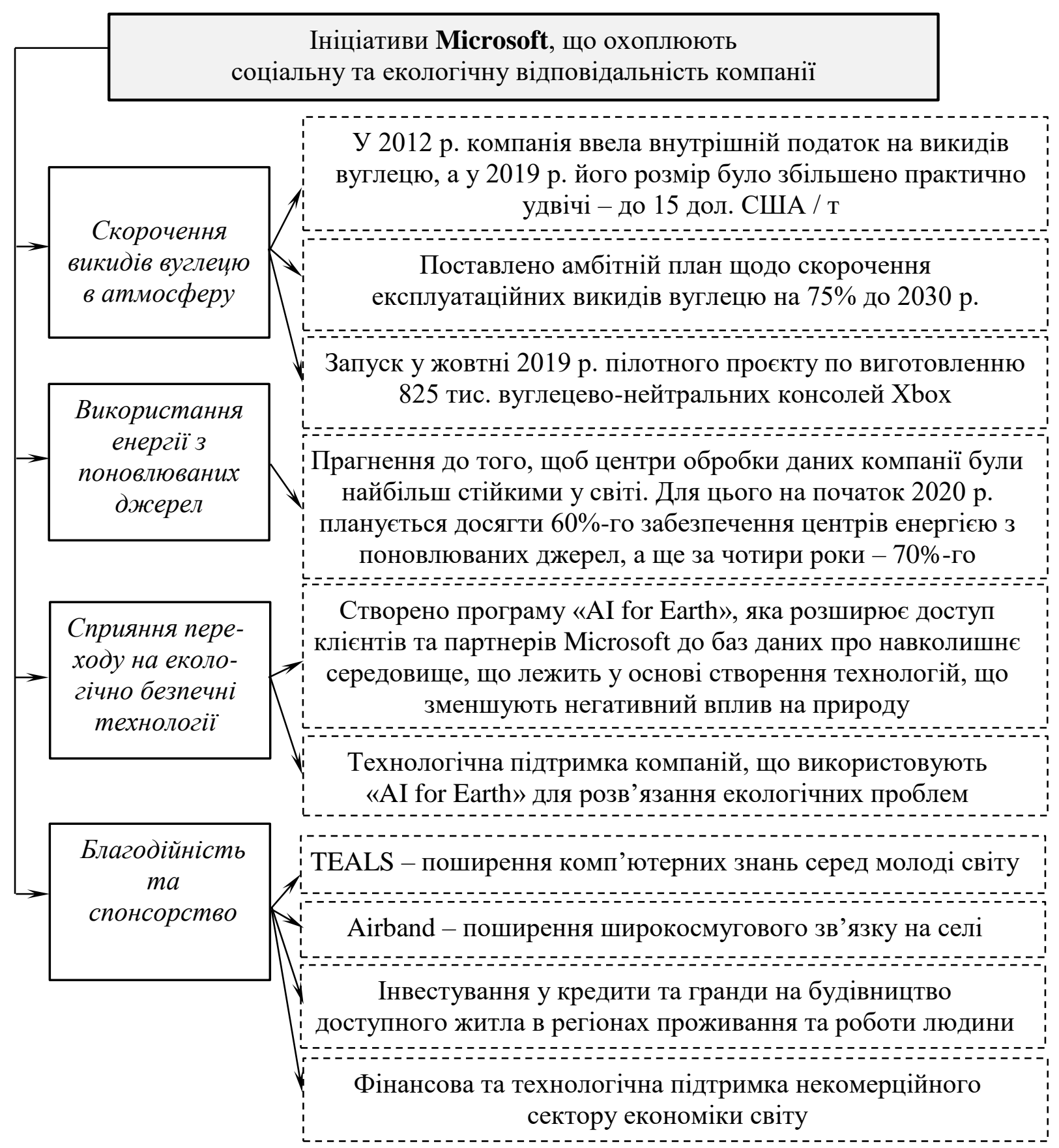

Рисунок 2 - Соціо-екологічні оріснтири діяльності компанії Microsoft Джерело: побудовано автором за даними [20]

Одним 3 напрямів реалізації соціально відповідальної поведінки перед суспільством Microsoft обрав розширення можливостей щодо «досягнення більшого для всіх учнів на планеті», що намагається реалізувати через створення продуктів для успішного опанування знаннями, що мотивують дитину до навчання і творчості; запровадження безкоштовних онлайн-курсів і заходів професійного розвитку для 
вчителів навчальних закладів різних рівнів; розробку для вчителя інструментів ефективного управління аудиторним часом; створення технологій управління навчальним закладом, що забезпечують повну конфіденційність інформації [20].

Microsoft визначає таке гасло своєї діяльності - людина має знати сьогоднішні технології, щоб бути максимально готовою до майбутнього. При цьому, щоб найбільш повно задовольнити потреби людини, в компанії запроваджено технологію «One Microsoft», яка заснована на швидкій реалізації підсвідомих потреб клієнта, які визначаються шляхом здійснення низки професійних прийомів співробітників.

Компанія Red Наt існувала протягом 1995-2019 рр. та була поглинута корпорацією IBM. Місією компаніє є створення програмного забезпечення з відкритим кодом, яке має продовжити розкривати потенціал всього світу та створення кращої основи для майбутнього IT. Основні ініціативи, що охоплюють соціальну та екологічну відповідальність компанії наведено на рис. 3.

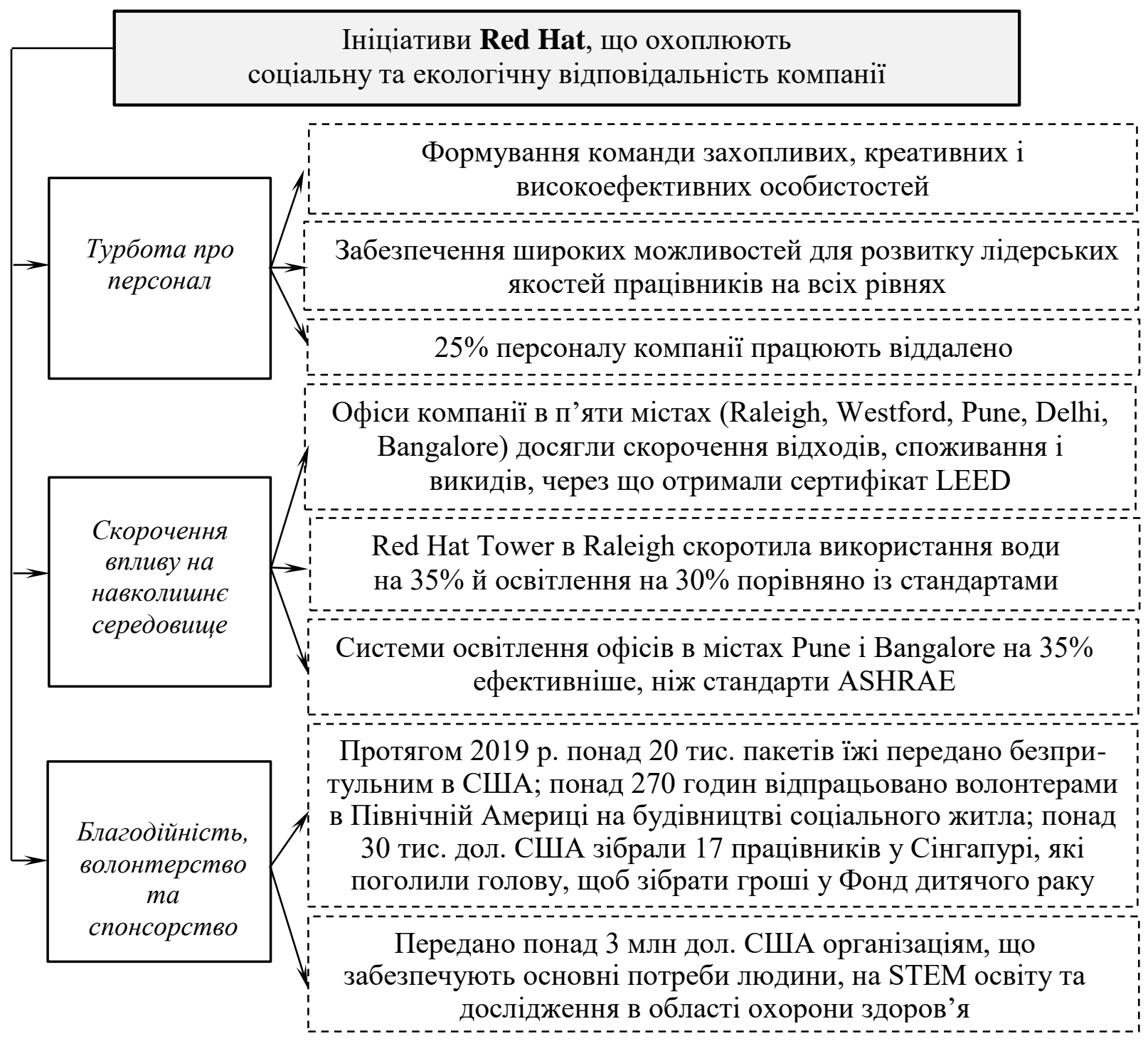

Рисунок 3 - Соціо-екологічні оріснтири діяльності компанії Red Hat Джерело: побудовано автором за даними [21] 
Компанія Red Hat вектором свого професійного розвитку обрала забезпечення всіх учасників ринкових відносин технологіями, що дозволить їм успішно адаптуватися, розв'язати наявні проблеми, що також є складовою її соціальної відповідальності перед суспільством.

Корпорація Apple поставила за мету досягти виробництва продукту без видобутку будь-яких нових копалин із землі. Для того, щоб реалізувати цю амбітну мету фахівці компанії безперервно розробляють нові інноваційні технології повторної переробки матеріалів дотримуючись при цьому жорстких вимог екологічної безпеки та безпеки для здоров'я людини. Місія компанії - виробляти найкращі продукти у світі, залишаючи при планету цьому у кращому стані (рис. 4).

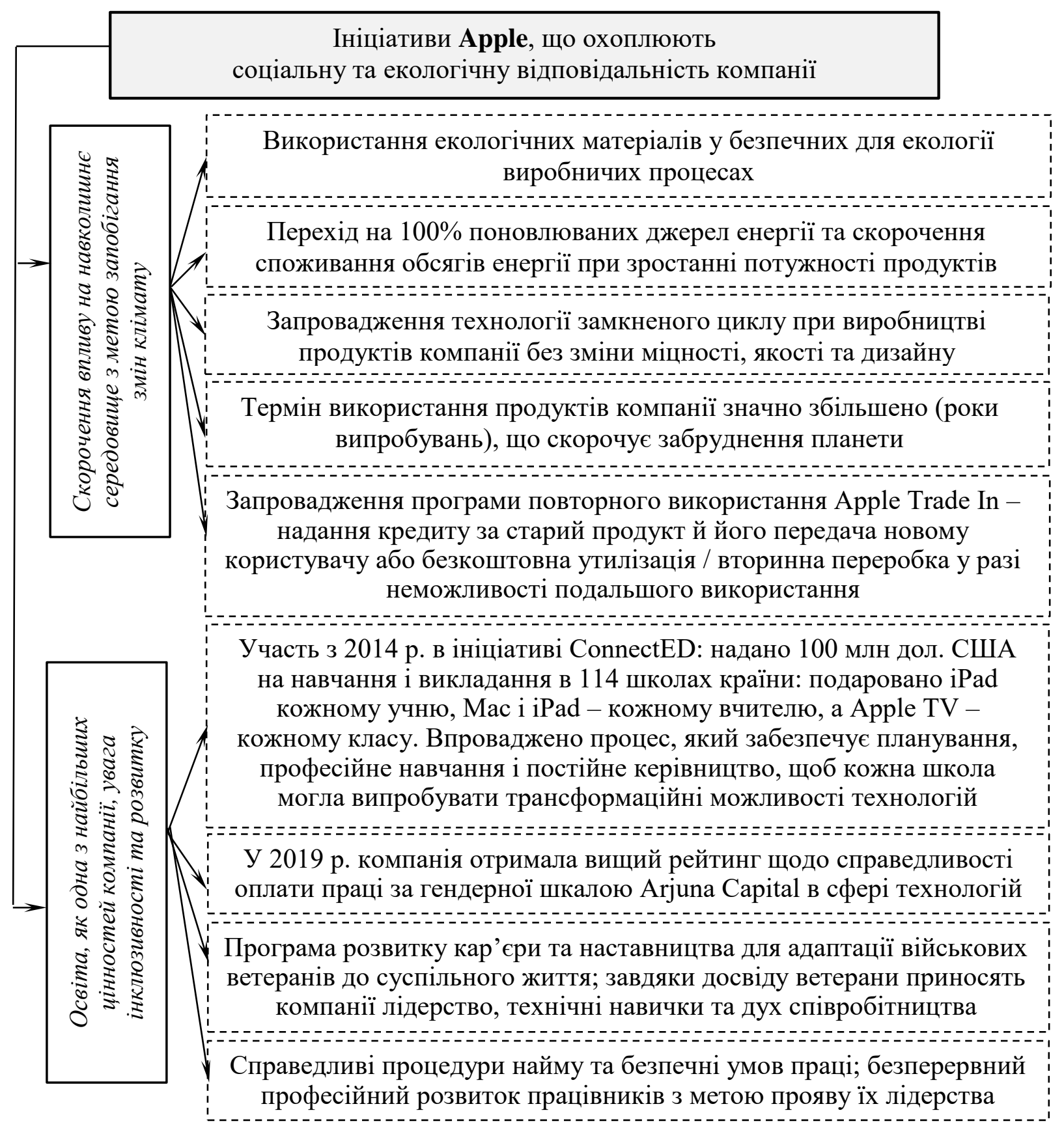

Рисунок 4 - Соціо-екологічні оріснтири діяльності компанії Apple Джерело: побудовано автором за даними [22] 
Продукти компанії Apple спрямовані на всебічне покращення життя людини полегшують й переводять у площину гри процеси навчання, отримання професійних знань та подальшого професійного розвитку; допомагають вчасно встановити проблеми iз здоров'ям, обрати найбільш ефективні технології лікування та реабілітації, забезпечити візуалізацію та безпечне збереження динамічних даних про стан здоров'я, надати всебічну й доступну медичну інформацію, значно підвищити рівень наукових досліджень у медичній сфері; забезпечують стовідсоткову конфіденційність особистої й професійної інформації й даних, безпеку й зручність у користуванні продуктами та технологіями компанії; забезпечують потужними інструментами досягнення успіху у будь-якій сфері бізнесу через запровадження суттєвих змін в кожну галузь, одночасно стимулюючи перехід на ресурсозбережний та екологічно чистий вид діяльності.

Метою діяльності німецької компанії SAP є допомога світу стати кращім й покращення життя людини. Коли у клієнтів з'являється важлива суспільна ідея розв'язання світових проблем, така як врятувати види, технологічно перетворити індустрію, нагодувати голодних, підтримати рівність або забезпечити допомогу по всьому світу тощо, фахівці компанії розробляють необхідну технологію, яка допоможе працювати 3 максимальною віддачею і досягти своєї мети [23]. Ці технології допомагають отримувати інформацію у реальному часі, долати перепони та приймати кращі управлінські рішення, щоб цікаві ідеї почали покращувати життя людини раніше. Основні ініціативи, що охоплюють соціальну та екологічну відповідальність компанії наведено на рис. 5.

Особливістю соціально відповідальної поведінки компанії SAP є не концентрація уваги на певних проблемах планети, а прагнення до розв'язання одночасно всіх проблем людства за допомогою цифрових технологій, провідних фахових знань та лідерських навичок фахівців. 3 цією метою компанія розширює клієнтську мережу, віддаючи перевагу компаніям, що розв’язують конкретну соціальну або екологічну проблему.

Проведене дослідження особливостей діяльності п'яти найкращих роботодавців світу за версією The world's best employers 19 дозволило продемонструвати лише найбільш яскраві приклади соціо-екологічних векторів розвитку, при тому, що соціальна й екологічна відповідальність є значно глибшою, більш різноманітнішою та апріорі покладеною в основу філософії існування кожної з досліджуваних компаній. У чистому вигляді адаптувати означений досвід в сучасних українських реаліях неможливо, проте доцільним $є$ узагальнення принципів соціо-екологічного вектору розвитку світових лідерів, поступове прийняття яких українськими підприємствами в якості керівних й основоположних дозволить створити передумови для побудови власного соціальновідповідального ділового середовища. У цьому контексті доцільним є виокремлення таких основних принципів успішної діяльності підприємства у напрямі соціоекологічного забезпечення:

1. Ощздливе відношення до навколишнього середовища - стратегічний перехід на раціональне використання природних ресурсів, заснований на запровадженні інноваційних технологій вторинного використання відходів, замкненого циклу водокористування, переведенні виробництва на відновлювальні джерела енергії та запобіганні всіх видів шкідливих викидів у зовнішнє середовище, пов'язаних із виробничо-господарською діяльністю підприємства. Цільова орієнтація діяльності на мінімізацію негативного впливу на планету при максимізації корисної допомоги при їі врятуванні від забруднення, зникнення багатьох біологічних видів, наслідків техногенних катастроф. 


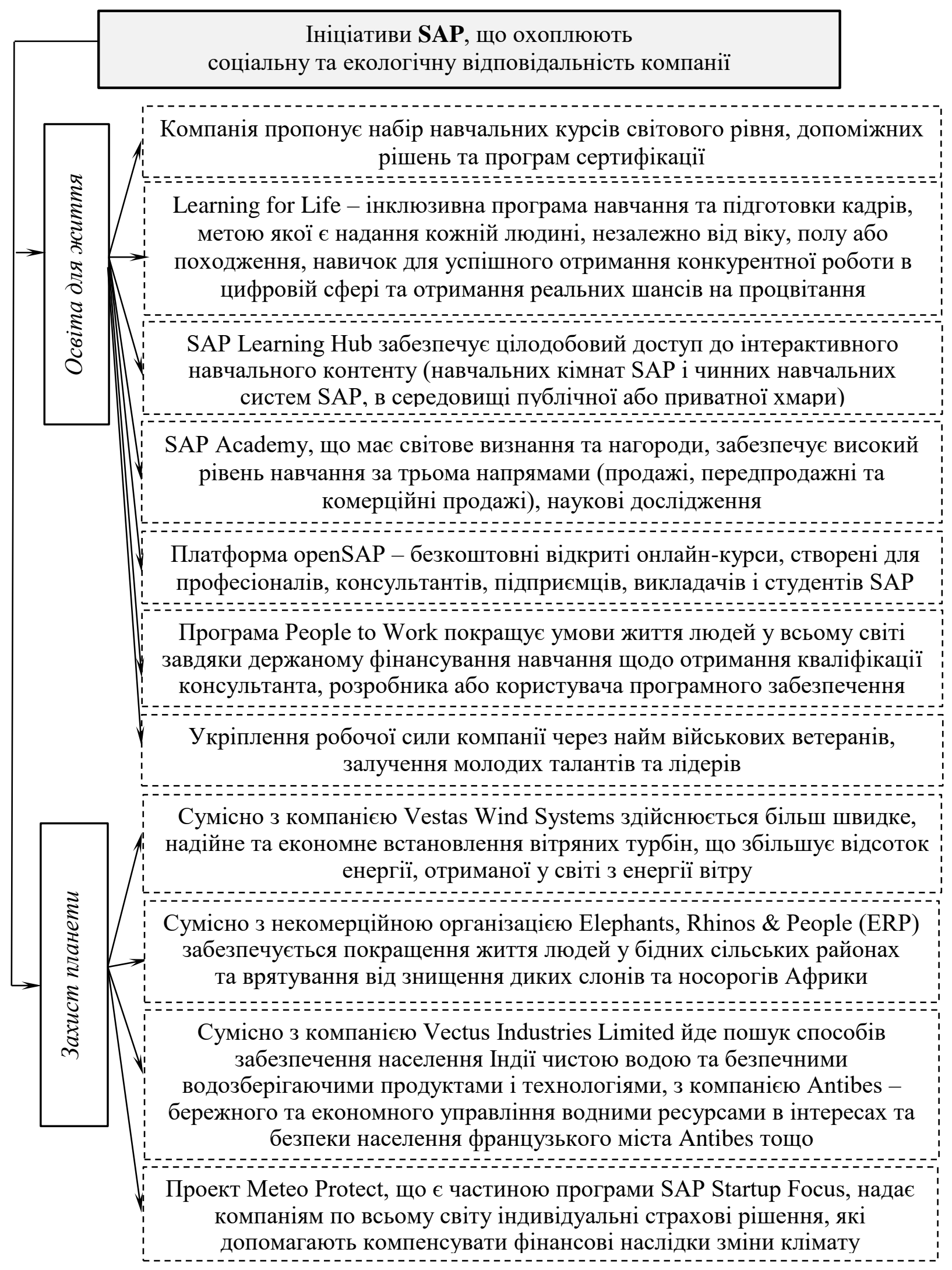

Рисунок 5 - Соціо-екологічні орієнтири діяльності компанії SAP Джерело: побудовано автором за даними [23] 
2. Збалансоване використання всіх факторів виробництва - соціально відповідальна політика діяльності підприємства має бути заснованою на раціональному використані всіх виробничих ресурсів, у тому числі й людських, що грунтується на прийнятті паритетних управлінських рішень, які за управлінською решіткою Р. Блейка та Дж.С. Моутон відповідають діагональним позиціям у діапазоні 5.5-10.10 та дозволить створити сприятливі умови для гармонійного розвитку всіх складових діяльності підприємства.

3. Професійний розвиток персоналу протягом життя та орієнтащія на таланти - запровадження на підприємстві диференційованої безперервної системи професійного навчання, стажування та підвищення кваліфікації всіх категорій персоналу та створення сприятливого середовища для залучення ззовні й розвитку всередині талантів, що дозволить сформувати підприємству у перспективі конкурентоспроможні позиції на регіональному, національному та міжнародному рівнях. Людиноцентристській підхід має бути побудованим на принципах забезпечення рівного доступу до суспільних благ всім людям регіону, країни та планети, надання можливостей до розкриття лідерських якостей та талантів.

4. Соціальний діалог і суспільна відповідальність - запровадження дієвої системи конструктивної взаємодії підприємства з регіональними органами влади та місцевою громадою, на території якої воно розташовано, у основу чого покладено його активну участь у суспільному житті та розв'язанні найбільш гострих соціально-економічних та екологічних проблем території. Благодійна, волонтерська та спонсорська діяльність мають стати основою забезпечення фінансово-економічної стабільності та прогресу підприємству.

Висновки. Реалії сучасного життя накладають певні вимоги на діяльність суб'єктів господарювання, додають соціо-екологічних характеристик стилю та змісту його управління. Так, сьогодні успішні підприємства розвинених країн світу під час реалізації прагнення стати економічно ефективними одночасно на добровільній основі беруть на себе виконання принципів соціальної корпоративної відповідальності, а саме в частині дотримання норм екологічної безпеки та створення сприятливих умов для соціального забезпечення потреб людини. Адаптація означеного підходу до умов функціонування українських підприємств дозволить закласти фундамент стабілізації регіональної та національної економіки й стане поштовхом для перспективного соціально-економічного розвитку країни. Саме тому подальші дослідження мають бути спрямованими на розробку механізму адаптації провідного світового досвіду, нагромадженого у сфері соціо-екологічного аспекту управління підприємства, до умов функціонування українських підприємств.

\section{СПИСОК ВИКОРИСТАНИХ ДЖЕРЕЛ}

1. Садеков А.А. Механизмы эколого-экономического управления предприятием: монография. Донецк: ДонГУЭТ им. Туган-Барановского, 2002. $311 \mathrm{c.}$

2. Дерій В.А. Облік, аудит і аналіз екологічної діяльності підприємств: поняття, стан та напрямки розвитку. Економічний аналіз. 2015. Т. 19. №2. С. 193-200.

3. Грицишен Д.О. Теоретико-методологічна конструкція еколого-економічного аналізу господарської діяльності промислових підприємств. Вісник ЖДТУ. 2015. №3 (73). С. 134143.

4. Латишева О.В. Етапи управління екологічною складовою потенціалу сталого розвитку машинобудівних підприємств. Економічний вісник Донбасу. 2016. №3 (45). С. 218-224. 
5. Скляр Л.Б. Діагностика як складова екологічного управління підприємством. Інновачійна економіка. 2014. №4 (53). С. 318-323.

6. Фещенко О.Л., Камнева Н.В. Теоретичні засади визначення поняття екологоекономічної безпеки підприємства. Університетські наукові записки. 2017. №61. С. 223231.

7. Прокопенко О.В., Школа В.Ю. Управління еколого-економічною безпекою підприємства на засадах екомаркетингу. Маркетинг і менеджмент інновацій. 2012. № 4. С.337-346.

8. Швиданенко Г.О., Криворучкіна О.В., Матукова Д.Г. Розвиток підприємства на еколого-економічних засадах: монографія. Київ: КНЕУ, 2017. 184 с.

9. Лібанова Е.М. Надмірна соціально неприйнятна нерівність: головний виклик для українського суспільства. Вісник Національної академії наук України. 2017. №5. С. $22-$ 25.

10. Колот А.М. Корпоративна соціальна відповідальність: еволюція та розвиток теоретичних поглядів. Економічна теорія. 2013. №4. С. 5-26.

11. Грішнова О.А., Магдич I.П. Економічна доцільність та пріоритетні напрями активізації соціальних інвестицій підприємств. Вісник Київського національного університету імені Тараса Шевченка. Економіка. 2016. Вип. 5. С. 13-18.

12. Новікова О.Ф., Дейч М.Є., Панькова В.О. Діагностика стану та перспектив розвитку соціальної відповідальності в Україні (експертні оцінки): монографія. Донецьк, 2013. 295c.

13. Комарницький І.Ф., Галушка 3.І. Соціальна відповідальність бізнесу як інструмент управління сучасним підприємством. Економічні науки. 2010. Вип. 6. С. 63-73.

14. Захарова О.В. Привабливий бренд роботодавця: умови створення та інструменти оцінки. Україна: аспекти пращуі. 2015. №4. С. 18-23.

15. Захарова О.В. Діагностика внутрішньої складової привабливості бренда роботодавця. Соціально-трудові відносини: теорія та практика. 3б. наук. пращь. Київ: ДВНЗ «Київський наџіональний економічний ун-т ім. В. Гетьмана». 2015. №2 (10). С. 62 70.

16. The world's best employers 2019 list. URL: https://www.forbes.com/lists/worlds-bestemployers/\#6e1435be1e0c.

17. Innovation in 2019. The Most Innovative Companies 2019. URL: https://www.bcg.com/publications/2019/most-innovative-companies-innovation.aspx.

18. Alphabet. URL: https://abc.xyz/.

19. Alphabet Inc. Quarterly report. FORM 10-Q. For the Quarterly Period Ended March 31, 2019. URL: https://abc.xyz/investor/static/pdf/20190429_alphabet_10Q.pdf?cache=7afe0eb.

20. Microsoft. URL: https://www.microsoft.com/.

21. Red Hat. URL: https://www.redhat.com/.

22. Apple. URL: https://www.apple.com/.

23. SAP. URL: https://www.sap.com/. 